\title{
Grønlands Geologiske Udvikling - fra urtid til nutid
}

Af J. Richard Wilson, Geologisk Institut, Aarhus Universitet

Grønlands geologiskeudvikling har fundet sted gennem 3.800 millioner år. Grønland domineres af indlandsisen, men langs randen af denne er der et isfrit område, der dækker ca. $410.000 \mathrm{~km}^{2}$. Det is-skurrede landskab og manglen på vegetationen betyder, at blotningsgraden og kvaliteten heraf ofte er fantastisk; den lange geologiske udvikling kan studeres i detaljer.

Forfatteren Niels Henriksen var ansat hos GEUS (og tidligere Grønlands Geologiske Undersøgelse) i mange år og har selv besøgt meget af Grønland. Han var chef for den geologiske kortlægning af Grønland og ekspeditionsleder i over 25 år. Den geologiske oversigtskortlægning af Grønland på en skala af 1:500.000 er nu færdig med udgivelse af 12 farvetrykte kort. Der er ingen bedre kvalificeret til at skrive en oversigtsbog over Grønlands geologi end Niels Henriksen.

\section{Bokse og ordforklaringer}

Bogen er forsøgt skrevet for ikke-fagfolk. Den geologiske udvikling behandles -i sagens natur - kronologisk med de ældste (og ofte mest indviklede) bjergarter først.

Læseren hjælpes gennem teksten med mange "bokse", hvor diverse processer, begreber og emner præsenteres på en tilgængelig måde. Der er over 50 bokse, som behandler emner så diverse som isostasi, metamorfose, absolutte aldersbestemmelser, pladetektonik, stratigrafi, opmåling af profiler, ichthyostega, sekvensstratigrafi, magma, dybhavsboringer, istidens klimasvingninger, de mineralske råstoffers kategorier, regler for efterforskning og minedrift samt olieefterforskning i Jameson Land.

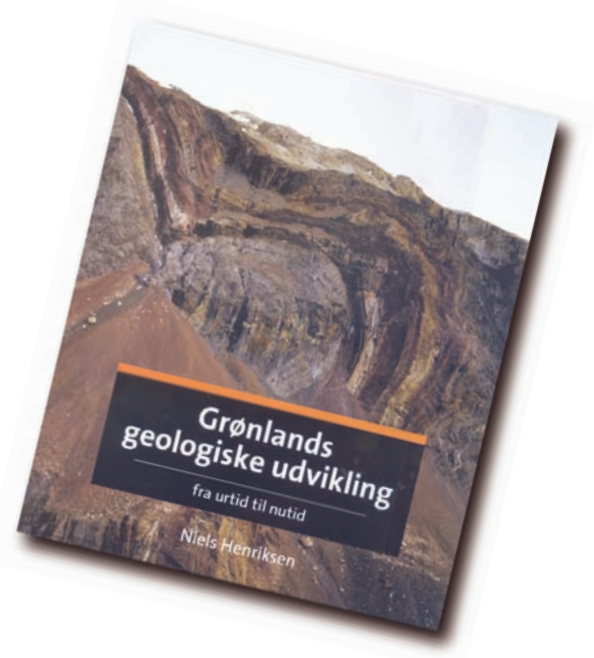

Der er også en 16 siders ordforklaring bagerst i bogen, efterfulgt af et stikordsregister (7 sider). De fleste feltfotos er udstyret med et lille grønlandskort, der viser, hvorfra i landet billedet er. Hvor det er relevant, indeholder kapitlerne et verdenskort, der viser beliggenheden af Grønland (for fx 390 millioner år siden) relativt til ækvator og kontinenterne.

\section{Kun få fejl}

Jeg har kun bemærket få fejl. Der nævnes "ultrabasiske silikatmineraler" på side 12; begrebet bruges for magmatiske bjergarter og ikke mineraler; “doloritisk” (side 35) skulle være doleritiske; der er problemer med skalaen på side 169 (enheder mangler), 195 (meget svært at læse målstok) og 214 (skalaen er i “m” men skulle være i “km”). Tolkningen af dannelsen af lagdelingen i Illimaussaq Intrusionen er ikke den, de fleste fagfolk tror på i dag. I nogle få tilfælde er illustrationerne for små og teksten for lille ( $\mathrm{fx}$ side 12-15), og billederne af håndstykkerne på side 34 lever ikke op til standarden af langt de fleste fotos.

Det er ikke let at skrive en bog af den art for ikke-fagfolk. Der er mange begreber i geologi, og bogen dækker en meget stort spektrum af faget. Med nogle ganske få undtagelser (som $\mathrm{fx}$ nefelinsyenit og de vanskelige og ofte eksotiske bjergartsnavne i Gardarprovinsen) er opgaven løst på en meget tilfredstillende måde.

Fantastiske fotos

Det bærende element gennem hele bogen er de fantastiske fotos af de grønlandske blotninger. Geologer, der arbejder i mindre velblottede områder, kan kun være misundelige! Nogle af de mest interessante kapitler for anmelderen (som er "hardrock-geolog") handler om undergrunden under havbunden omkring Grønland og de mineralske råstoffer. I sagens natur er der ikke mange fotos af blotninger under havbunden, men de velkonstruerede profiler er meget illustrative, og den geologiske historie velskrevet.

Mineralske råstoffer præsenteres på en tilgængelig måde, og beskrivelsen af den tidligere minedrift er spændende læsning. Potentialet for økonomiske fund af mineralråstoffer samt olie og gas, som også behandles, viser, at de geologiske undersøgelser på og omkring Grønland langt fra er færdige.

\section{En bog der kan anbefales}

Grønlands Geologiske Udvikling-fra urtid til nutid - er en flot bog. Forfatteren må gratuleres med et imponerende resultat. De få småfejl trækker ikke ned i min vurdering af denne bog som et stort bidrag til den danskskrevne litteratur om geologi. Jeg kan anbefale bogen til alle geologi-interesserede - både fagfolk og ikke-fagfolk. De førstenævnte vil få belyst mange emner, hvor de ikke selv har ekspertisen; de sidstnævnte vil få deres interesse for geologi forstærket.

Nu mangler der bare en tilsvarende bog om Danmarks geologi!

Skrevet af Niels Henriksen. Udgivet af GEUS oktober 2005. 270 sider. Pris: 290 kroner inklusiv moms, men eksklusiv forsendelse. Bogen kan købes hos: GEUS (bogsalg@geus.dk) eller Geografforlaget Aps (go@geografforlaget.dk). ISBN: 877871-163-0 